\title{
Conduct, Performance, and Dilemmas of Inter-organizational Virtual Organizing
}

\author{
A Literature Review
}

\author{
Sanjeev Jha ${ }^{1}$ and Mary Beth Watson-Manheim ${ }^{2}$ \\ 1 College of Business Administration, University of Illinois, Chicago, \\ Illinois, USA, sjha2@uic.edu \\ 2 College of Business Administration, University of Illinois, Chicago, \\ Illinois, USA, mbwm@uic.edu
}

\begin{abstract}
Firms are increasingly embedded in networks of relationships with other organizations that are of strategic importance. An organization's participation in a network may provide access to information, resources, markets, and technologies, or it may lock it in unproductive relationships from which it may be difficult to extricate. Therefore, it is no longer adequate to analyze firms' conduct and performance by examining firms in isolation from their network partners. Strategy research has investigated inter-organizational alliances for some time. However, the primary focus of this research has been to examine the antecedents of network formation and relatively lesser attention has been paid to the implications of alliances and networks on a firm's performance. Since virtual organizations are conceptualized as strategic networks and alliances among organizations, we examined literature on virtual organizations to understand what has been done in inter-organizational context. We found 34 papers out of a total of 117 papers on virtual organization that examined virtual organizing at inter-organizational level. We classified each of the short-listed papers by virtual organizing type (network membership, network structure, tie modality, and time-frame), performance, and dilemmas of virtual organizing. Our analyses showed that interorganization virtual organizing strategy varied with the goals of virtual organizing. Across the short-listed papers we found a pattern of organizing that depended on whether organizing was for abstract resources (knowledge, skills, competencies, etc.) or for specific goals (outsourcing key components). Virtual organizing for abstract resources tended to exhibit decentralized network structure and collaborative ties with partners, while virtual organizing for specific goals tended to exhibit centralized network structure and opportunistic ties. We found a lack of empirical literature examining the process of inter-organization virtual organizing strategy and its consequences.
\end{abstract}

Please wse the following format when ciling this chapter:

Jha, S., Watson-Manheim, M.B., 2007, in IFIP International Federation for Information Processing, Volume 236, Virtuality and Virtualization; eds. K. Crowston, Sieber, S., Wynn, E., (Boston: Springer), pp. 35-50. 


\section{Introduction}

Firms are increasingly embedded in networks of relationships with other organizations, even across continents, which are of strategic importance. An organization's participation in a network may provide access to information, resources, markets, and technologies, or it may lock it in unproductive relationships from which it may be difficult to extricate. Therefore, it is no longer adequate to visualize and analyze firms' conduct and performance by examining firms in isolation from its network partners [1]. In other words, understanding a firm's conduct and performance may not be complete until one comprehends strategic advantages or disadvantages a firm accrues because of its membership to networks composed of business partners, such as suppliers, customers, competitors, or other entities.

Strategy research has investigated inter-organizational alliances for some time. However, the primary focus of this research has been to examine the antecedents of network formation and relatively lesser attention has been paid to the implications of alliances and networks on a firm's performance [2]. Specifically, how does participation in networks influence firms' conduct and performance?

The view of strategic networks and alliances among organizations has been termed a virtual organization beginning with Davidow and Malone [3]. Thus, it is reasonable to believe that this set of literature on virtual organizations may address specific questions applying to conduct and performance of firms in virtual interorganizational relationships. Our objective in this study is to understand what previous literature on virtual organization has done in inter-organizational context. Specifically, what does past research say about the conduct and performance of interorganizational virtual organization? The rest of the paper is organized as follows. First, we discuss the theory behind inter-organizational virtual organizing. In the next two sections we discuss the methods and results of the study. In the following three sections we present the discussion, limitations, and conclusions of this study respectively.

\section{Background}

Venkatraman and Henderson [4] argue that virtualness of an organization is a strategy and not an organizational structure. The authors emphasize that the term "virtual organization" is an unfortunate term, while the term "virtual organizing" connotes a powerful strategy that focuses on organizing virtually for knowledge and intellect to create business value. They conceptualize virtual organizing to have three vectors and three stages. The three vectors of virtual organizing are: customer interaction (virtual company-to-customer interactions); asset configuration (virtual business to business interactions); and knowledge leverage (virtual sourcing of expertise). The three stages of virtual organizing are at task unit level, organizational level, and inter-organizational level. In this paper, we focus on the third stage of virtual organizing, the inter-organizational virtual organizing (IOVO). This stage is the most challenging because participating organizations may have different aspirations and organizing strategy. However, the rewards are plentiful if networks 
are managed well as members gain strength from each other's resources. Henceforth, in this paper, we conceptualize an inter-organizational virtual network of relationships as an IOVO strategy. The authors identify performance objectives of IOVO to be sustained innovation and growth.

Apart from the performance issues, the other interesting aspect to examine in case of inter-organizational networks is the dilemmas of organizing strategy. For instance, Dyer and Nobeoka [5] studied the knowledge-sharing network of Toyota and its suppliers to uncover and explain how Toyota managers solved the following three fundamental dilemmas of knowledge sharing: (1) motivate members to participate and openly share valuable knowledge (while preventing undesirable spillovers to competitors), (2) prevent free rider, and (3) reduce the cost of finding and accessing different knowledge. It is important to note two important characteristics of Toyota and its suppliers' knowledge-sharing network. First, Toyota is at the centre of the network guiding and managing its suppliers. Second, the knowledge-sharing network is enduring, where the entire network benefits from learning from each other, providing a sustainable competitive advantage against the networks of other automakers.

To the best of our knowledge, only two studies have reviewed literature on virtual organizations: Schultze and Orlikowski [6] and Watson-Manheim et al. [7]. Schultze and Orlikowski [6], in their seminal paper, reviewed practitioner-directed literature on virtual organizing to identify metaphors that characterized virtuality. In the absence of real experience of the new way of organizing virtually, the authors stressed that metaphors convey the characteristics of organizing. To their credit, the authors identified 5 overarching metaphors from the selected 17 articles from 3 of the best practitioner journals. The search terms used to select the articles were: "virtual organizing," "virtual organizations," "virtuality," and "virtual work." Watson-Manheim et al. [7] carried out a literature review to develop a precise understanding of the term "virtual" used to describe changing work environments. The authors proposed a framework to classify changing work environments based on the type of discontinuities involved in the work. The authors used the search terms "virtual work" and "virtual organization" to select past literature.

In this paper, our objective is to take stock of the literature on virtual organization to understand the ways of IOVO organizing (conduct), challenges of IOVO organizing (dilemmas), and whether IOVO organizing mattered or not (performance). In some sense this is an extension of Schultze and Orlikowski [6], wherein the authors identified five virtual organizing types: organizing as platform, as existing in space, as composed of bits, as operating as a community, and as engaging in a network of relationships. Also, as mentioned above, since strategy literature has identified the research gap and stressed the criticality of understanding the conduct and performance of organizational networks, we believe studies on IOVO strategy may guide practitioners and researchers.

\section{Methods}

The objective of this paper is to understand the conduct, consequences, and dilemmas of IOVO strategy. Accordingly, we searched for published articles, both 
conceptual and empirical, that examined IOVO. We chose EBSCOhost and JSTOR databases to look for the articles. The search terms ("virtual organizing," "virtual organization(s)," "virtuality," and "virtual work") were taken from Schultze and Orlikowski [6], which included the two search terms in Watson-Manheim et al. [7]. These search terms resulted in 117 articles on virtual organizations. We manually inspected each of the 117 articles to segregate IOVO papers. Our manual inspection resulted in 34 articles that addressed the issue of virtual organizing in interorganizational context.

Next, we analyzed each of the 34 short-listed articles according to the framework derived from the objectives of our study. The framework has five components of IOVO: Goals/performance; dilemmas; research approach; context of the study; and organizing type. We discuss five components:

1. Goals/ performance of IOVO strategy: We identify the central objective of IOVO strategy in each of the selected short-listed papers.

2. Dilemmas of IOVO strategy: We identify the challenges of IOVO strategy in each of the selected short-listed papers.

3. The Research Approach: Following are terms used to classify articles based on research approach [7]: Field research, survey; Field research, case study; Conceptual; Theoretical, model building; Simulation; Prescriptive.

4. IOVO Strategy Characteristics: We adapt the characteristics of IOVO strategy from Gulati et al. [1] to understand how organizations conduct themselves in inter-organizational relationships. The authors mention the following first three characteristics of strategic networking strategy and to this list we added the time-frame dimension:

Network membership: This refers to the composition of the network, which includes complementary resources, sharing of risks, access to market, etc. In this paper we have clubbed skills, competencies, capabilities, technology, capital, etc. as resources.

Network structure: This refers to the overall pattern of relationships among partners. We have classified IOVO strategy promoting either centralized or decentralized network structure. Centralized network structure is organized around a focal firm [8] and therefore a centralized IOVO strategy has a central firm virtually organizing members around it. Focal firms accrue disproportionate benefits compared to other members in terms of knowledge or financial rewards. In contrast, in decentralized IOVO strategy all members are equal and there is no formal focal firm organizing the activities of members.

Tie modality: This refers to the rules and norms of virtual organizing. Based on Gulati et al. [1], we classified IOVO strategy as collaborative or opportunistic. In collaborative ties the benefits are distributed fairly among members, while in opportunistic ties members are driven by self-interest and more concerned about their own benefits [9]. Collaborative ties are win-win relationships where imbalances in rewards even out in the long run, while opportunistic ties are those where members are less concerned about the overall benefit of others or in equity in reward sharing. For example, a phrase like "common interests" was classified as collaborative IOVO 
strategy, while a phrase like "organizing contractually or other means" was classified as opportunistic.

Time-frame: Apart from the above three, we found IOVO strategy also differed by time-frame. Authors in the selected papers put emphasis on the temporality of virtual organizing strategy. Accordingly, we classified IOVO strategy as short-term or long-term. For example, Toyota and its supplier have a stable, long-term strategic alliance, where all the members benefit from each other [5]. We found several papers that have conceptualized IOVO strategy to be short-term for specific business opportunity.

5. Context of IOVO strategy. We identify the context of the field research or conceptual study for better understanding of the consequences of virtual organizing strategy. There is a huge variation in the contexts of virtual organizing: Global Water Partnership [10]; outsourcing of key components [11]; research \& design VO; cyber community of teachers [12]; energy industry in Sweden [13]. As Venkatraman and Henderson [4] emphasize, virtual organizing is a strategy applicable to all kinds of organizations; however, the way of organizing may differ.

The five components of the coding of articles were mutually agreed upon after several rounds of discussion. While, one of the authors coded the articles, the other checked the coding to refine the coding. Disagreements helped in further refining the coding of articles.

\section{Results}

We found only 3 empirical papers out of the 34 short-listed papers on IOVO strategy (see Table 1). Out of these three, Lin and Lin [12] is a case study of a cyber community of teachers. Ahuja and Carley [8] is another case study of a VO engaged in research and design. The third paper, Kraut et al. [11], employed survey methodology to study the linkage between usage of electronic networks and outsourcing of key components. We discuss the results of these studies in the following paragraphs. However, it is important to note that two of the three empirical

Table 1: Research approaches in the selected papers.

\begin{tabular}{|c|l|c|}
\hline S. No. & Research Approach & No. of papers \\
\hline 1 & Ficld rescarch, survey & 1 \\
\hline 2 & Field research, case study & 2 \\
\hline 3 & Conccptual & 29 \\
\hline 4 & Theoretical, model building & 1 \\
\hline 5 & Simulation & 1 \\
\hline 6 & Prescriptive & 1 \\
\hline Total & & 34 \\
\hline
\end{tabular}

Note: The total is less than the column sum because one article matched multiple research approach

papers study non-commercial organizations. In other words, only one of the 34 papers is an empirical study based on commercial organizations. The majority of the 
papers are still conceptual, discussing the mechanisms, goals, and dilemmas of organizing virtually.

We have classified the short-listed papers into three broad groups: empirical papers (Table 2); conceptual papers conceiving virtual organizing as a long-term strategy (Table 3); and conceptual papers conceiving virtual organizing as a shortterm strategy (Table 4).

Table 2: Empirical papers

\begin{tabular}{|l|l|l|l|l|l|}
\hline & Goals/performance & Dilemmas & $\begin{array}{l}\text { Network membership; } \\
\text { structure; tie modality }\end{array}$ & Context \\
\hline $\begin{array}{l}\text { Creating new } \\
\text { knowledge, ncw } \\
\text { education }\end{array}$ & $\begin{array}{l}\text { Trust; creation } \\
\& \text { sharing } \\
\text { knowledge }\end{array}$ & $\begin{array}{l}\text { Resources; } \\
\text { Decentralized; } \\
\text { Collaborative }\end{array}$ & $\begin{array}{l}\text { Cyber } \\
\text { community } \\
\text { of teachers }\end{array}$ \\
\hline & No. of publications & $\begin{array}{l}\text { Motivating } \\
\text { members to } \\
\text { get involved. }\end{array}$ & $\begin{array}{l}\text { Rcsources; Centralized; } \\
\text { Collaborative }\end{array}$ & $\begin{array}{l}\text { Case study } \\
\text { of a research } \\
\& \text { design } \\
\text { VO. }\end{array}$ \\
\hline & $\begin{array}{l}\text { Outsourcing of key } \\
\text { components }\end{array}$ & $\begin{array}{l}\text { Opportunism } \\
\& \text { complcxity } \\
\text { of } \\
\text { transactions. }\end{array}$ & $\begin{array}{l}\text { Resources; Centralized; } \\
\text { Opportunistic }\end{array}$ & $\begin{array}{l}\text { Survey of } \\
250 \\
\text { managers in } \\
\text { four } \\
\text { industrics }\end{array}$ \\
\hline
\end{tabular}

The first group, of three empirical papers discussed above (presented in Table 2), has three different contexts. Lin and Lin [12] did a case study of SCTNet, a cyber community of teachers, which metaphorically functions as a platform where teachers participate to create new knowledge. Virtual organizing is collaborative to share domain knowledge, short-term, for a specific project, and most importantly VO is decentralized. The dilemmas are teachers' attitudes towards sharing and creation of knowledge. The other two empirical papers, by Ahuja and Carley [8] and by Kraut et al. [11], discuss virtually organizing strategy for number of publications and outsourcing of key components respectively. There is a similarity in their characteristics of virtual organizing as they are both organizing for members' resources; however, there is dissimilarity in tie modality as Ahuja and Carley [8] emphasize collaborative ties among researchers, while Kraut et al. [11] hint at opportunistic ties among members. But unlike Lin and Lin [12], both of these studies have centralized network structure for long-term virtual organizing. Kraut et al. [11] mention that the major dilemmas are the focal firms' vulnerability to opportunism and complexity of transactions, which may force them to produce in-house. Ahuja and Carley [8] mention the challenge of motivating members to identify and involve with the group.

In the second group, we found five conceptual papers that stressed virtual organizing to be a long-term strategy (presented in Table 3). The first set of three papers has goals of creating knowledge assets and dilemmas of dissipation of core competencies and decision-making through consensus in a network of equal partners. For example, Holmberg [10] discusses the case of Global Water Partnership, wherein 
the members share expertise and experience in water management, but are concerned about swifter and better decision making in the absence of a brokering body. The second set of the last two papers has a manufacturing context. For example, Upton and McAfee [14] discuss how factories can virtually organize to collectively design products, enable suppliers to electronically bid for jobs, and level the field for small and big suppliers. The dilemmas for the focal firm here are creation of conflicting goals, reduced openness, and trust. Both of these sets of papers organize virtually for members' resources, but the key difference is in their characteristics of network structure and tie modality. Organizing for knowledge assets, as in the first set of papers, the authors have conceptualized virtual organizing structure to be decentralized and tie modality to be collaborative; while organizing for production, as in the second set of papers, the authors have conceptualized virtual organizing structure to be centralized with a focal entity overseeing the organizing strategy and tie modality to be opportunistic.

Table 3: Conceptual papers conceiving virtual organizing as long-term

\begin{tabular}{|c|c|c|c|c|}
\hline Study & $\begin{array}{c}\text { Goals/ } \\
\text { performance }\end{array}$ & Dilemmas & $\begin{array}{l}\text { Network membership; } \\
\text { structure; tie modality }\end{array}$ & Context \\
\hline [28] & $\begin{array}{l}\text { Knowledge \& } \\
\text { skills }\end{array}$ & & $\begin{array}{l}\text { Resources; } \\
\text { Decentralized; } \\
\text { Collaborative }\end{array}$ & $\begin{array}{l}\text { Possible in } \\
\text { more developed } \\
\text { parts of the } \\
\text { society }\end{array}$ \\
\hline [29] & Knowledge assets & $\begin{array}{l}\text { Dissipation of } \\
\text { core } \\
\text { competencies }\end{array}$ & $\begin{array}{l}\text { Resourccs; } \\
\text { Decentralized; } \\
\text { Collaborative }\end{array}$ & $\begin{array}{l}\text { Forum on } \\
\text { technology } \\
\text { management }\end{array}$ \\
\hline$[10]$ & Knowledge & $\begin{array}{l}\text { Politicking; low } \\
\text { membership }\end{array}$ & $\begin{array}{l}\text { Resources; } \\
\text { Decentralized; } \\
\text { Collaborative }\end{array}$ & $\begin{array}{l}\text { Global Water } \\
\text { Partnership }\end{array}$ \\
\hline [14] & $\begin{array}{l}\text { Design products; } \\
\text { Bid for jobs }\end{array}$ & & $\begin{array}{l}\text { Resources; Centralized; } \\
\text { Opportunistic }\end{array}$ & $\begin{array}{l}\text { Virtual factory, } \\
\text { a community of } \\
\text { factories }\end{array}$ \\
\hline$[30]$ & $\begin{array}{l}\text { Flexibility, quick } \\
\text { response to market }\end{array}$ & $\begin{array}{l}\text { Conflicting } \\
\text { goals; openness, } \\
\text { trust }\end{array}$ & $\begin{array}{l}\text { Resources; Centralized; } \\
\text { Opportunistic }\end{array}$ & $\begin{array}{l}\text { Low level of } \\
\text { direct } \\
\text { ownership }\end{array}$ \\
\hline
\end{tabular}

The third group has 26 conceptual papers, which is more than $76 \%$ of the shortlisted papers (Table 4). These papers visualize virtual organizing to be short-term and most of them organize primarily for access to members' resources. A few of the papers also discuss the importance of shared risks and access to each other's markets. A careful study of these papers shows that the first 19 of these papers have a conceptualized virtual organizing to have decentralized network structure. Of these 19 papers, only 2 papers profess that members should organize opportunistically to select partners for specific opportunities. The rest of the papers argue for collaborative organizing in a decentralized network structure. Broadly, there are four goals of virtual organizing in these papers: small firms can pose threat to large 
established firms; exploiting global business opportunities, speed of uniting critical competencies, and flexibility in choosing and removing partners.

The rest of the seven papers in the third group have conceptualized virtual organizing to have a centralized network structure and of these, five papers stress the importance of organizing opportunistically. While, Lynch et al. [15] discuss the success of VOs in the US federal government and emphasize how Cooperative Administrative Support Units (CASUs) virtually organize collaboratively, Fitzpatrick and Burke [16] argue for organizing through formal contractual linkage. Broadly, five of the seven papers discuss virtual organizing in a manufacturing context; the other two are in the context of electronic commerce and the US federal government.

\section{Discussion}

Need for empirical research: Despite the fact that it has been more than a decade since the idea of IOVO originated [3], little empirical research has been done to understand the conduct, performance, and dilemmas of inter-organizational virtual organizing and still fewer in commercial organization settings. We believe, more empirical research needs to be done to guide organizations appropriately in their IOVO strategy. Specifically, how the conduct (network membership, network structure, tie modality, and time-frame of organizing) influences performance and the dilemmas that organizations need to address for successful virtual organizing.

Although, we found little evidence of rigorous empirical research on IOVO strategy, we believe organizations are increasingly practicing IOVO strategy. We find evidence of this discussed in recent innovation literature emphasizing the importance of organizations' alliances with business partners across the globe to fruitfully engage in solving business problems. A spate of recent practitioner literature attests to the criticality of organizing for innovation beyond organizational boundary: era of open innovation [17]; open market innovation [18]; global innovation process [19]; networking for successful innovation [20]; outsourcing innovation [21]; sourcing innovation [22]; and many others. Two examples of organizations that immediately come to our mind, that have begun networking extensively with business partners are Proctor \& Gamble and Boeing. P\&G reinvented their innovation business model. A. G. Lafely, the CEO of P\&G, set a target of $50 \%$ of their product innovations to come from outside and $50 \%$ from inside [23]. Boeing, unlike past projects, actively solicited business partners in the innovation process for a new 787 jetliner, the Dreamliner project [24]. In sum, more research is needed to understand the process and consequences of IOVO.

IOVO Strategy: We found IOVO strategy varies with the goals of virtual organizing. Across empirical papers (Table 2), conceptual long-term virtual organizing papers (Table 3), and conceptual short-term virtual organizing papers (Table 4), we found a pattern of organizing that depended on whether organizing was for abstract resources (knowledge, skills, competencies, etc.) or specific goals (outsourcing key components). Barring a few exceptions, virtual organizing for abstract resources had decentralized network structure and collaborative ties with 
partners, while virtual organizing for specific goals had centralized network structure and opportunistic ties.

The latter kind of organizing for specific goals seems to be more prevalent in practice than any outsourcing relationship [16], as focal firms attempt to be opportunistic and retain most of the powers in the network. However, this kind of opportunistic strategy does not necessarily yield a win-win strategy. Members may leave the network or may not share resources and eventually everybody loses. The dilemmas of organizing (trust, identity, dissipation of competencies, etc.) may doom the networking strategy pre-maturely, especially when compounded with the above challenges and when organizing duration is short-term.

The former kind of organizing seems to be more idealistic, especially if the time frame is short-term. The goals are abstract and the organizing strategy is to have a decentralized structure and collaborative ties among members. Kasper-Fuehrer and Ashkanasy [25] have aptly called this a "Weberian-ideal-type" IOVO strategy. This may be akin to the metaphors identified by Schultze and Orlikowski [6]. However, we do not rule out the possibility of this kind of short-term, decentralized, and collaborative IOVO strategy working successfully in some industry or knowledge work. We submit that more research needs to be done in this area. For now we, along with the authors, wonder how organizations will overcome the dilemmas this ideal type of IOVO strategy pose. For example, flexibility demands substitutable links, while creating new competencies requires stability to harness members' expertise [26]. We believe there is immense scope for doing research in understanding how IOVO strategy impacts performance.

Dilemmas of IOVO: In the beginning of the paper, we mentioned the example of dilemmas of knowledge sharing network at Toyota and its suppliers. Toyota and its suppliers have a knowledge sharing network that is centralized and for the long term benefit of the partners. The major dilemmas that they face are motivating members to participate in the network, preventing free rider, and reducing the cost of finding and accessing different knowledge [5]. The reasons why Toyota has successfully solved the dilemmas of inter-organizational networking seem to emanate from their unique and thoughtful organizing strategy: network structure is centralized (Toyota as a strong focal firm), tie modality seems to be collaborative (Toyota taking interest in the performance of suppliers), and time-frame is long-term. Over a period of time all the network members benefit by making the knowledge-sharing network a success. The only paper that came close to describing this organizing type was Ahuja and Carley [8], though the network is not composed of commercial organizations.

What we find from the short-listed papers is that the IOVO strategy militates against successfully resolving the dilemmas of organizing. For example, Mowshowitz [27] mentions that excessive switching may increase rather than reduce costs and also cause image problems. Although the dilemmas by themselves look similar to that of the Toyota case, the papers have not addressed how IOVO strategy will successfully resolve the dilemmas. How do you resolve the issues of trust (identity, dissipation of competencies, etc.) when IOVO strategy is long-term, centralized, but opportunistic (Table 2, 3); when IOVO strategy is short-term, decentralized, and collaborative (Table 2, 4); when IOVO strategy is long-term, decentralized, and collaborative (Table 3); when IOVO strategy is short-term, 
centralized, and opportunistic (Table 4)? Future research may examine how IOVO strategy resolves dilemmas of organizing.

\section{Limitations}

This study has two major limitations. First, we searched for relevant articles from only two major databases (EBSCOhost and JSTOR). There are other databases like $A B I /$ Inform, which we did not investigate, because of paucity of time and also because EBSCOhost and JSTOR are two of the largest articles databases. We believe we would have gotten more of the same articles rather than different articles from other databases. This also makes us believe that the absence of articles that we may have inadvertently omitted may not have significantly biased our findings. Second, since we focused on only the published articles, we may have also advertently omitted unpublished studies like dissertations, conference articles, or work-inprogress (WIP) articles on IOVO. We conveniently assume that most of the important conference and WIP articles may have been published in journals. However, we do admit that we may have missed some of the unpublished articles. We also want to submit that including all of them is beyond the scope of our study. Despite these limitations, we believe that the 35 articles we chose are representative of the research done with an IOVO perspective.

\section{Conclusions}

Our analyses show that IOVO strategy varies with the goals of virtual organizing. Across the short-listed papers, empirical and conceptual, long-term and short-term, we found a pattern of organizing that depended on whether organizing was for abstract resources, knowledge, skills, competencies, etc., or for specific goals, outsourcing key components. Virtual organizing for abstract resources had decentralized network structure and collaborative ties with partners, while virtual organizing for specific goals had centralized network structure and opportunistic ties. Virtual organizing for abstract resources seems to be a more ideal kind of IOVO strategy, while organizing strategy for specific goals seems familiar from general network relationships. However, more research is needed to understand the process of virtual organizing and its impact on performance and in addressing the dilemmas successfully, especially since a large proportion of the short-listed papers are still conceptual. Also, as we mentioned above, practitioner literature on innovation has emphasized the importance of strategic networks and some of the large organizations seem to be orchestrating strategic alliances, so more rigorous research is needed to unravel the process of IOVO. 
Our contribution lies in classifying the papers by the characteristics of IOVO strategy (network membership, network structure, tie modality, and time-frame), dilemmas, and goals of virtual organizing. To the best of our knowledge no one has classified papers in this way.

Table 4: Conceptual papers conceiving virtual organizing as short-term

\begin{tabular}{|c|c|c|c|c|}
\hline Study & $\begin{array}{l}\text { Goals/performanc } \\
\text { e }\end{array}$ & Dilemmas & $\begin{array}{l}\text { Network membership; } \\
\text { structure; tie modality }\end{array}$ & Context \\
\hline [31] & $\begin{array}{l}\text { Small firms can } \\
\text { pose threat to large } \\
\text { firms }\end{array}$ & $\begin{array}{l}\text { Demanding } \\
\text { partners \& } \\
\text { customers; }\end{array}$ & $\begin{array}{l}\text { Resources; } \\
\text { Decentralized; } \\
\text { Collaborative }\end{array}$ & $\begin{array}{l}\text { VO as a future } \\
\text { form of } \\
\text { organization }\end{array}$ \\
\hline [32] & $\begin{array}{l}\text { Small firms can } \\
\text { pose threat to large } \\
\text { firms }\end{array}$ & $\begin{array}{l}\text { Managerial } \\
\text { vacuum } \\
\text { geographical \& } \\
\text { cultural distances }\end{array}$ & $\begin{array}{l}\text { Resources; } \\
\text { Decentralized; } \\
\text { Collaborative }\end{array}$ & $\begin{array}{l}\text { Six small firms } \\
\text { want to create } \\
\text { 'virtual web' }\end{array}$ \\
\hline$[27]$ & $\begin{array}{l}\text { Flexibility \& } \\
\text { responsiveness } \\
\text { lower costs. }\end{array}$ & $\begin{array}{l}\text { Excessive } \\
\text { switching } \\
\text { between business } \\
\text { partners }\end{array}$ & $\begin{array}{l}\text { Resources; Centralized } \\
\text { or decentralized; } \\
\text { Opportunistic }\end{array}$ & $\begin{array}{l}\text { Consistent with all } \\
\text { forms of } \\
\text { organization }\end{array}$ \\
\hline [33] & $\begin{array}{l}\text { To access global } \\
\text { business } \\
\text { opportunity. }\end{array}$ & & $\begin{array}{l}\text { Resources; } \\
\text { Decentralized; } \\
\text { Collaborative }\end{array}$ & $\begin{array}{l}\text { An industrial } \\
\text { virtual enterprise }\end{array}$ \\
\hline [34] & $\begin{array}{l}\text { Quickly assemble } \\
\text { broad ranges of } \\
\text { resources }\end{array}$ & & $\begin{array}{l}\text { Resources; } \\
\text { Decentralized or } \\
\text { centralized; } \\
\text { Collaborative } \\
\end{array}$ & $\begin{array}{l}\text { Applications of } \\
\text { Artificial } \\
\text { Intelligence (AI) } \\
\text { in VOs. }\end{array}$ \\
\hline [35] & $\begin{array}{l}\text { Gaining access to } \\
\text { new global markets. }\end{array}$ & & $\begin{array}{l}\text { Resources; } \\
\text { Decentralized or } \\
\text { centralized; } \\
\text { Collaborative }\end{array}$ & $\begin{array}{l}\text { Pursue a specific } \\
\text { global market } \\
\text { opportunity }\end{array}$ \\
\hline [36] & $\begin{array}{l}\text { Flcxibility, } \\
\text { adaptability, \& } \\
\text { Efficiency } \\
\end{array}$ & $\begin{array}{l}\text { Economic } \\
\text { dependence on } \\
\text { partners }\end{array}$ & $\begin{array}{l}\text { Resources; } \\
\text { Decentralized; } \\
\text { Collaborative }\end{array}$ & $\begin{array}{l}\text { Industrial } \\
\text { organization. }\end{array}$ \\
\hline [25] & $\begin{array}{l}\text { Swiftly coming } \\
\text { together to exploit a } \\
\text { market }\end{array}$ & $\begin{array}{l}\text { Trust, loyalty, } \\
\text { profit sharing, } \\
\text { making business } \\
\text { strategy }\end{array}$ & $\begin{array}{l}\text { Resources; } \\
\text { Decentralized; } \\
\text { Collaborative }\end{array}$ & $\begin{array}{l}\text { Weberian-ideal } \\
\text { type definition of } \\
\text { lOVO }\end{array}$ \\
\hline [37] & $\begin{array}{l}\text { Exploiting a market } \\
\text { opportunity }\end{array}$ & $\begin{array}{l}\text { Trust, common } \\
\text { business } \\
\text { understanding }\end{array}$ & $\begin{array}{l}\text { Resources; } \\
\text { Decentralized; } \\
\text { Collaborative }\end{array}$ & $\begin{array}{l}\text { Proposes a theory } \\
\text { of trust }\end{array}$ \\
\hline
\end{tabular}


Table 4 Continued: Conceptual papers conceiving virtual organizing as short-term

\begin{tabular}{|c|c|c|c|c|}
\hline Study & Goals/performance & Dilemmas & $\begin{array}{l}\text { Network membership; } \\
\text { structure; tie modality }\end{array}$ & Context \\
\hline$[38]$ & $\begin{array}{l}\text { Speed business } \\
\text { solutions }\end{array}$ & $\begin{array}{l}\text { Sharing } \\
\text { sensitive } \\
\text { information } \\
\text { with partners }\end{array}$ & $\begin{array}{l}\text { Resources; Decentralized; } \\
\text { Collaborative }\end{array}$ & $\begin{array}{l}\text { Applicable to all } \\
\text { industry }\end{array}$ \\
\hline [39] & $\begin{array}{l}\text { Collectively exploit } \\
\text { opportunities }\end{array}$ & $\begin{array}{l}\text { Regions that } \\
\text { lack } \\
\text { sophistication } \\
\text { cannot be } \\
\text { tapped }\end{array}$ & $\begin{array}{l}\text { Resources; Decentralized; } \\
\text { Opportunitsitc }\end{array}$ & $\begin{array}{l}\text { IT enabling agility } \\
\& \text { global } \\
\text { expansion }\end{array}$ \\
\hline$[40]$ & $\begin{array}{l}\text { Adaptability } \\
\text { flexibility, agility, \& } \\
\text { speed }\end{array}$ & $\begin{array}{l}\text { Loss of control } \\
\text { of functions \& } \\
\text { information }\end{array}$ & $\begin{array}{l}\text { Resources; Decentralized; } \\
\text { Collaborative }\end{array}$ & $\begin{array}{l}\text { Parnters quickly } \\
\text { link resources \& } \\
\text { capabilities }\end{array}$ \\
\hline [41] & $\begin{array}{l}\text { Dynamix business } \\
\text { process }\end{array}$ & $\begin{array}{l}\text { Conflict, } \\
\text { loyalty, } \\
\text { coherent } \\
\text { identity,greater } \\
\text { alienation. } \\
\end{array}$ & $\begin{array}{l}\text { Resources; Decentralized; } \\
\text { Collaborative }\end{array}$ & $\begin{array}{l}\text { Special Issue: } \\
\text { Communication } \\
\text { proceses Vos. }\end{array}$ \\
\hline$[42]$ & $\begin{array}{l}\text { Exploit fast } \\
\text { changing } \\
\text { opportunities. }\end{array}$ & $\begin{array}{l}\text { Managing HR: } \\
\text { staffing, } \\
\text { rewarding, } \\
\text { assigning work }\end{array}$ & $\begin{array}{l}\text { Resources; Decentralized; } \\
\text { Collaborative }\end{array}$ & $\begin{array}{l}\text { Importance of } \mathrm{HR} \\
\text { in the success of } \\
\text { Vos, }\end{array}$ \\
\hline [43] & $\begin{array}{l}\text { Speed growth, } \\
\text { flexibility, } \\
\text { profitability }\end{array}$ & & $\begin{array}{l}\text { Resources; Decentralized; } \\
\text { Collaborative }\end{array}$ & $\begin{array}{l}\text { New business } \\
\text { model }\end{array}$ \\
\hline [26] & $\begin{array}{l}\text { Flexibility and } \\
\text { responsiveness. } \\
\text { Knowledge. }\end{array}$ & $\begin{array}{l}\text { Inhibit } \\
\text { flexibility and } \\
\text { change, } \\
\text { autonomy } \\
\end{array}$ & $\begin{array}{l}\text { Resources; Decentralized; } \\
\text { Collaborative }\end{array}$ & $\begin{array}{l}\text { VO in an } \\
\text { electronic market } \\
\text { environment. }\end{array}$ \\
\hline [44] & $\begin{array}{l}\text { Market quickly, } \\
\text { increased product } \\
\text { improvements }\end{array}$ & & $\begin{array}{l}\text { Resources; Decentralized; } \\
\text { Collaborative }\end{array}$ & $\begin{array}{l}\text { Agile practices, } \\
\text { chemical industry }\end{array}$ \\
\hline [45] & $\begin{array}{l}\text { Adaptability, } \\
\text { flexibility, react } \\
\text { quickly to changes }\end{array}$ & $\begin{array}{l}\text { Management } \\
\text { coordination } \\
\text { may become } \\
\text { an issue. }\end{array}$ & $\begin{array}{l}\text { Resources; Decentralized; } \\
\text { Collaborative }\end{array}$ & $\begin{array}{l}\text { Agile practices, } \\
\text { chemical industry }\end{array}$ \\
\hline [46] & $\begin{array}{l}\text { Leveraging on } \\
\text { shared } \\
\text { competencies, } \\
\text { shorten devlopment } \\
\text { times }\end{array}$ & $\begin{array}{l}\text { Commitment, } \\
\text { identity, \& } \\
\text { trust. Sharing } \\
\text { info. }\end{array}$ & $\begin{array}{l}\text { Resources; Decentralized; } \\
\text { Collaborative }\end{array}$ & $\begin{array}{l}\text { Bio Region, } \\
\text { Biotechnology } \\
\text { industry }\end{array}$ \\
\hline [47] & $\begin{array}{l}\text { Efficiency \& } \\
\text { responsiveness }\end{array}$ & & $\begin{array}{l}\text { Resources; Centralized; } \\
\text { Opportunistic }\end{array}$ & $\begin{array}{l}\text { Vos in context of } \\
\text { electronic } \\
\text { commerce. }\end{array}$ \\
\hline
\end{tabular}


Table 4 Continued: Conceptual papers conceiving virtual organizing as short-term

\begin{tabular}{|l|l|l|l|l|}
\hline Study & Goals/performance & Dilemmas & $\begin{array}{l}\text { Network membership; } \\
\text { structure; tie modality }\end{array}$ & Context \\
\hline$[48]$ & $\begin{array}{l}\text { Global } \\
\text { competitivencss. } \\
\text { Local } \\
\text { responsiveness }\end{array}$ & $\begin{array}{l}\text { Coordination } \\
\text { costs Traditional }\end{array}$ & $\begin{array}{l}\text { Resources; Centralized; } \\
\text { Opportunistic }\end{array}$ & $\begin{array}{l}\text { Strategies \& } \\
\text { transnational } \\
\text { organization. }\end{array}$ \\
\hline $\begin{array}{l}\text { Strategic flexibility, } \\
\text { Cost efficicncy, } \\
\text { competitiveness }\end{array}$ & $\begin{array}{l}\text { Not all firms may } \\
\text { successfully } \\
\text { organize virtually }\end{array}$ & $\begin{array}{l}\text { Resources; Centralized; } \\
\text { Opportunistic }\end{array}$ & $\begin{array}{l}\text { Discusses two } \\
\text { forms of Vos }\end{array}$ \\
\hline $\begin{array}{l}\text { Access global } \\
\text { markets. Morc } \\
\text { complcte product. }\end{array}$ & $\begin{array}{l}\text { Difficulty in } \\
\text { managing } \\
\text { towards final } \\
\text { goal }\end{array}$ & $\begin{array}{l}\text { Resources; Centralized; } \\
\text { Opportunistic }\end{array}$ & $\begin{array}{l}\text { Two VOs in } \\
\text { energy industry } \\
\text { in Sweden. }\end{array}$ \\
\hline$[4]$ & $\begin{array}{l}\text { Compctitive } \\
\text { advantage, } \\
\text { Sustained } \\
\text { innovation \& } \\
\text { growth }\end{array}$ & $\begin{array}{l}\text { Managing } \\
\text { competition \& } \\
\text { coopcration. }\end{array}$ & $\begin{array}{l}\text { Rcsources; Centralized; } \\
\text { Opportunistic }\end{array}$ & $\begin{array}{l}\text { Powerful concept } \\
\text { applicablc to all } \\
\text { organizations. }\end{array}$ \\
\hline $\begin{array}{l}\text { Responsive, } \\
\text { competitive, \& } \\
\text { flexible. }\end{array}$ & $\begin{array}{l}\text { Organizational \& } \\
\text { product flexibility } \\
\text { to respond to } \\
\text { changcs. }\end{array}$ & $\begin{array}{l}\text { Trust, } \\
\text { information } \\
\text { privacy } \\
\text { modularity may } \\
\text { weaken ties }\end{array}$ & $\begin{array}{l}\text { Resources; Centralized; } \\
\text { Opportunistic }\end{array}$ & $\begin{array}{l}\text { Supply chain } \\
\text { management. }\end{array}$ \\
\hline 49$]$ & $\begin{array}{l}\text { Resources; Centralized; } \\
\text { Collaborative }\end{array}$ & $\begin{array}{l}\text { Success of VOs } \\
\text { in the US Federal } \\
\text { Govt. }\end{array}$ \\
\hline
\end{tabular}

\section{References}

1. R. Gulati, N. Nohria, and A. Zaheer, Strategic Networks, Strategic Management Journal 21, 203-215 (2000b).

2. R. Gulati, N. Nohria, and A. Zaheer, Guest Editors' Introduction to the Special Issue: Strategic Networks, Strategic Management Journal 21, 199-201 (2000a).

3. W. H. Davidow and M. S. Malone, The Virtual Corporation: Structuring and Revitalizing the Corporation of the 21st Century (Harper Collins, New York, 1992).

4. N. Venkatraman and J. C. Henderson, Real Strategies for Virtual Organizing, Sloan Management Review Fall, 33-48 (1998).

5. J. H. Dyer and K. Nobeoka, Creating and Managing a High-performance KnowledgeSharing Network: The Toyota Case, Strategic Management Journal 21, 345-367 (2000).

6. U. Schultze and W. J. Orlikowski, Metaphors of Virtuality: Shaping an Emergent Reality, Information and Organization 11, 45-77 (2001).

7. M. B. Watson-Manheim, K. M. Chudoba, and K. Crowston, Discontinuities and Continuities: A New Way to Understand Virtual Work, Information Technology \& People 15(3), 191-209 (2002). 
8. M. K. Ahuja and K. M. Carley, Network Structure in Virtual Organizations, Organization Science 10 (6), 741-757 (1999).

9. J. Galaskiewicz and A. Zaheer, Networks of Competitive Advantage, in: Research in the Sociology of Organizations, edited by S. Andrews and D. Konke (JAI Press, Greenwich, CT, 1999) pp. 237-261.

10. J. Holmberg, Knowledge-intensive Networks for Development: The Case of the Global Water Partnership, Human Systems Management 17 (1), 39-47 (1998).

11. R. Kraut, C. Steinfield, A. P. Chan, B. Butler, and A. Hoag, Coordination and Virtualization: The Role of Electronic Networks and Personal Relationships, Organization Science 10 (6), 722-740 (1999).

12. F. Lin and S. Lin, A Conceptual Model for Virtual Organizational Learning, Journal of Organizational Computing and Electronic Commerce 11(3), 155-178 (2001).

13. P. Bosch-Sijtsema, A Structure of Roles Within Virtual Organizations, International Journal of Information Technology \& Decision Making 1 (3), 371-384 (2002).

14. D. M. Upton and A. McAfee, The real virtual factory, Harvard Business Review JulyAugust, 123-133 (1996).

15. T. D. Lynch, C. E. Lynch, and R. D. White, Jr., Public Virtual Organizations, International Journal of Organizational Theory and Behavior 3(3\&4), 391-412 (2000).

16. W. M. Fitzpatrick and D. R. Burke, Form, Functions, and Financial Performance Realities for the Virtual Organization, SAM Advanced Management Journal Summer, 13$20(2000)$.

17. H. W. Chesbrough, (2003) The Era of Open Innovation, MTT Sloan Management Review Spring, 35-41 (2003).

18. D. Rigby and C. Zook, Open Market Innovation, Harvard Business Review October, 8089 (2002).

19. J. Santos, Y. Doz and P. Williamson, Is Your Innovation Process Global?, MIT Sloan Management Review Summer, 31-37 (2004).

20. P. Rozova, Are You Networked for Successful Innovation?, MIT Sloan Management Review Spring, 49-55 (2006).

21. J. B. Quinn, Outsourcing Innovation: The New Engine of Growth, MIT Sloan Management Review Summer, 13-28 (2000).

22. J. C. Linder, S. Jarvenpaa, and T. H. Davenport, Toward an Innovation Sourcing Strategy, MIT Sloan Management Review Summer, $43-49$ (2003).

23. L. Huston and N. Sakkab, Connect and Develop: Inside Proctor \& Gamble's New Model for Innovation, Harvard Business Review March, 58-66 (2006).

24. S. Kotha and R. Nolan, Boeing 787: The Dreamliner, Harvard Business School, Cases 9305-101 (2005).

25. E. C. Kasper-Fuehrer and N. M. Ashkanasy, The Interorganizational Virtual Organization, International Studies of Management and Organization 33(4), 34-64 (2003).

26. J. Burn and M. Barnett, Communicating for Advantage in the Virtual Organization, IEEE Transactions On Professional Communication 42 (4), 215-222 (1999).

27. A. Mowshowitz, Virtual Organization, Communications of the ACM 40(9), 30-37 (1997).

28. C. Faucheux, How Virtual Organizing is Transforming Management Science, Communications of the ACM, 40 (9), 50-55 (1997).

29. J. Blau and M. F. Wolff, Global Networking Poses Management Challenge/Risk, Research Technology Management 40(1), (1997). 
30. M. Alexander, Getting to Grips with the Virtual Organization, Long Range Planning 30(1), 122-124 (1997).

31. Z. Rahman and Bhattachryya Virtual Organization: A Strategem, Singapore Management Review 24, 2, 29-45 (2002).

32. U. J. Franke, The Virtual Web as a New Entrepreneurial Approach to Network Organizations, Entrepreneurship \& Regional Development 11, 203-229 (1999).

33. M. Hardwick and R. Bolten, The Industrial Virtual Enterprise, Communications of the ACM 40(9), 59-60 (1997).

34. D. E. O'Leary, D. Kukka, and R. Plant, Artificial Intelligence and Virtual Organizations, Communications of the ACM 40(9), 52-59 (1997).

35. C. Speier, M. G. Harvey and J. Palmer, Virtual Management of Global Marketing Relationships, Journal of World Business 33(3), 263-276 (1998).

36. W. W. Cooper and M. L. Muench, Virtual Organizations: Practice and the Literature, Journal of Organizational Computing and Electronic Commerce 10(3), 189-208 (2000).

37. E. C. Kasper-Fuehrer and N. M. Ashkanasy, Communicating Trustworthiness and Building Trust in Interorganizational Virtual Organizations, Journal of Management 27, 235-254 (2001).

38. S. L. Goldman, From Bricks to Bytes, Healthcare Forum Journal 41(3), (1998).

39. S. A. Morris and D. J. McManus, Information Infrastructure Centrality in the Agile Organization, Information Systems Management Fall, 8-12 (2002).

40. T. J. Strader, F. Lin, and M. J. Shaw, Information Infrastructure for Electronic Virtual Organization Management, Decision Support System 23, $75-94$ (1998).

41. G. DeSanctis and P. Monge, Introduction to the Special Issue: Communication Processes for Virtual Organizations, Organization Science 10(6), 693-703 (1999).

42. J. Coyle and N. Schnarr, The Soft-side Challenges of the Virtual Corporation, Human Resource Planning 18(1), 41-42 (1995).

43. D. Walters and J. Buchanan, The New Economy, New Opportunities, and New Structures, Management Decision 39(10), 818-833 (2001).

44. A. Guisinger and B. Ghorashi, Agile Manufacturing Practices in the Specialty Chemical Industry, International Journal of Operations \& Production Management 24(6), 625-635 (2004).

45. M. M. Weber, Measuring Supply Chain Agility in the Virtual Organization, International Journal of Physical Distribution \& Logistics Management 32(7), 577-590 (2002).

46. U. Weisenfeld, O. Fisscher, A. Pearson, and K. Brockhoff, Managing Technology as a Virtual Enterprise, R\&D Management 31(3), 323-334 (2001).

47. O. Khalil and S. Wang, Information Technology Enabled Meta-management for Virtual Organizations, International Journal of Production Economics 75, 127-134 (2002).

48. M. Boudreau, K. D. Loch, D. Robey, and D. Straub, Going Global: Using Information Technology to Advance the Competitiveness of the Virtual Transnational Organization, Academy of Management Executive 12(4), 120-128 (1998).

49. A. Chandrashekar and P.B. Schary, Towards the Virtual Supply Chain: The Convergence of IT and Organization, International Journal of Logistics Management 10(2), 27-39 (1999). 


\begin{abstract}
About the Authors
Sanjeev Jha is a Doctoral Student in the Department of Information \& Decision Sciences in the College of Business Administration, University of Illinois at Chicago (UIC). His research interests are innovation management, virtual organizing, knowledge management, organizational learning, information technology (IT) adoption, and strategic information systems (IS). He has published articles in journals such as Knowledge and Process Management, Research-Technology Management, Communications of the ACM, Information Resources Management Journal, and IEE Engineering Management. His co-authored papers have been presented at conferences such as Academy of Management (AOM), International Conference in Information Systems (ICIS), Organizations and Society in Information Systems (OASIS), Americas Conference in Information Systems (AMCIS), Workshop on e-Business (WEB), and ISOneWorld.

Mary Beth Watson-Manheim is an Associate Professor in the Information \& Decision Sciences Department and Director of the Center for Research in Information Management in the College of Business Administration at the University of Illinois, Chicago. She obtained her Ph.D. in Information Technology Management from Georgia Institute of Technology. Her publications have appeared in journals such as MIS Quarterly, Journal of Management Information Systems, IEEE Journal of Systems, Man and Cybernetics, Information Systems Journal, MIS Quarterly Executive, Information Technology and People, and Group Decision and Negotiation and others. Prior to obtaining her $\mathrm{PhD}$, she worked in the telecommunications industry for approximately 10 years. She is involved in research on issues related to the integration of information and communication technologies (ICT) and organizational work, and ICT-enabled organizational change. Her research has been funded by Intel Corporation, IBM Corporation, Lotus Development Corporation, and various university centers.
\end{abstract}

